\title{
Technology and Content Integration for English Language Learners in a Vocational High School
}

\author{
Ebru ATADİL-KUZUCU 1 (D) Günizi KARTAL*2(D) \\ ${ }^{1}$ Sadabad Anatolia High School, İstanbul, Turkey, ebru.atadil@gmail.com \\ ${ }^{2}$ Boğaziçi University, Faculty of Education, İstanbul, Turkey, gunizi.kartal@boun.edu.tr \\ * Corresponding Author: gunizi.kartal@boun.edu.tr
}

Article Info

\begin{abstract}
This exploratory study investigated the effectiveness of technology and content integration in a foreign language class in a vocational high school with a total of 41 students. The experimental group received technology-enhanced content integrated instruction, designed specifically for learning needs based on scaffolding design guidelines for educational software. The control group followed the regular textbook. In addition to scaffolding e-books developed for the study, freely available web-based and augmented reality applications were employed. The results showed that the experimental group significantly outperformed the control group in content tests, one of the language tests, and a writing task. No significant difference was observed between the groups in the general language test, but within group comparisons showed significant increased for the experimental group for sub-test scores. Recommendations are offered for the teachers, researchers, and policy makers seeking solutions for the low foreign language achievement in vocational high schools.

To cite this article: Atadil-Kuzucu, E. \& Kartal, G. (2020). Technology and content integration for english language learners in a vocational high school. Journal of Computer and Education Research, 8 (15), 114-135. DOI: $10.18009 /$ jcer.656133
\end{abstract}

Received: 6 December 2019

Accepted: 8 January 2020

Keywords: Technology-integration, scaffolding software, content-based instruction, EFL in vocational high school.

10.18009/jcer.656133

Publication Language: English

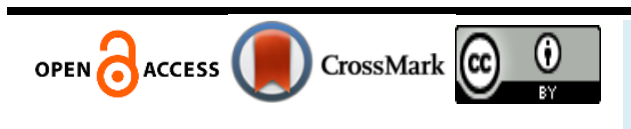

\section{Introduction}

Technology integrated learning environments have become a need not only because proper technology integration helps enhance learning but also because being born into a digital world have changed the ways in which students learn (Bransford et al. 2000; Prensky, 2001). The foreign language classroom is one of the places where technology has often been recommended, because language learning requires authenticity that digital tools can help provide. Technology can also enable a learner-centred environment, which is a key component for language learning.

Content integration into language classes, such as in Content-based Instruction (CBI), enables this authenticity by supplying the language class with meaningful content. The students learn authentic academic content in a language in which they are still learning, as 
$\mathrm{CBI}$ programs are intended to improve both language and content knowledge at the same time (Snow \& Brinton, 1997). Although technology has been perceived as an effective way to increase authenticity, technology integration into CBI is relatively new (Chapelle \& Jamieson, 2008), and there is not much research on both technology and content integration.

Foreign language classes are supposed to be a place where all learners are engaged in meaningful language use in an anxiety-free environment (Crandall, 1993). However, traditional textbook-based language lessons fail to achieve these conditions, since the focus is generally on form rather than meaning or function of language use. One way to create an engaging learning environment is to contextualize the language curriculum in meaningful content as in CBI. However, it may be difficult to find common content for all learners in a classroom (Carrel \& Carson, 1997). Working with a group of learners who share the same characteristics and interests, or work at the same workplace would overcome this problem. Therefore vocational schools seem ideal places to implement CBI, as they bring together students in a common vocational area and goals. Although the Turkish Ministry of National Education has designed Vocational English courses for some departments in vocational high schools, it has not been adopted for all areas of study, and implementations are very rare.

This study is an attempt to bridge a double-gap: designing simultaneous technology and content integration in an English as a foreign language course, and implementing it in a vocational high school, where approaches such as CBI would make most sense, and even nationally recommended by the Ministry of Education for language teaching. The effects of this model on language achievement and domain-specific knowledge are investigated at very low English proficiency levels in a limited-technology context. Technology integration was designed based on the scaffolding design guidelines for educational software proposed by Quintana, Reiser, Davis, Krajcik, Fretz, Duncan, and Soloway (2004).

\section{Literature Review}

\section{Content-based instruction and technology integration}

$\mathrm{CBI}$ is one of the earliest approaches to language learning that promotes authentic contexts for language learning. It is defined as integrating language learning with content mastery (Stryker \& Leaver, 1997) to create a meaningful academic context and increase the motivation to learn a new language (Snow, Met, \& Genesee, 1989). Language and content mastery are seen as a simultaneous process rather than a sequential action (Wesche \& 
Skehan, 2002). Therefore, CBI assures learners to master their content and language skills simultaneously. In this approach, content and language teachers cooperate and design the CBI curricula accordingly.

Putting language and content together in a lesson is not enough to call a course CBI. Both the language and content materials need to be selected purposefully, and be modified in accordance with the students' proficiency levels in both areas. While all CBI programs comprise content and language integration, to which degree this integration takes place will differ based on the model preferred. Content and Language Integrated Learning (CLIL), a more recent approach, aims to improve competency in the target language and content by giving equal importance to both (Marsh, Mehisto, Wolff, \& Frigols Martin, 2010). The instructional content is derived from a content subject rather than everyday life or target language culture (Marsh, 2012). In a recent meta-analysis on the effects of CLIL, Graham, Choi, Davoodi, Razmeh, and Dixon (2018) argued that the effects of CLIL on learning outcomes have not been unequivocal, and therefore recommended further research on CBI outcomes in different learning contexts in a variety of countries. Nonetheless, better performance on standardized language tests at primary and secondary levels (Coral, Lleixà, \& Ventura, 2018), and positive language outcomes for tertiary level Tourism students (Yang, 2015) were reported in the literature.

Although CBI was implemented in Turkey in 1980s in several Anatolian High Schools where the primary medium of instruction is English, it has been recently adapted only in private schools that have a lot more hours of language instruction than regular schools (Yalçın, 2013). While a number of studies yielded significant results in favour of following a theme-based syllabus in elementary and secondary schools (Alptekin, Erçetin, \& Bayyurt, 2007) as well as in college (Yalçın, 2012), there has not been much research on content integration in foreign language teaching in Turkey.

Technology use in foreign language teaching has been extensively researched in various contexts and with a variety of digital tools (Bush \& Terry, 1997; Haley \& Austin, 2013). However, few studies have been carried out to assess the effectiveness of technology integration in CBI (Chapelle \& Jamieson, 2008). There has been some research on English for Special Purposes (ESP) courses especially in teaching business English. However, ESP courses do not aim at achieving both content and language mastery as in CBI. 
Erçetin (2011) developed mobile assisted language learning materials used in a vocational English course for tourism vocational high school students in Turkey. Mobile technology was employed as supplementary material that included reading, listening, vocabulary, and grammar related components. The participants found the materials effective and enjoyable. Kasper (2000) investigated the effects of internet use on a CBI course on environmental sciences. The results showed that the pass rates of the students in the experimental group and their language proficiency levels were significantly higher than the other classes who followed a regular curriculum. The few studies on technology integrated ESP and CBI courses have made it clear that technology helps learners to increase not only their motivation but also language mastery if used appropriately.

\section{Scaffolding in Language Learning and Software Design}

Scaffolding is defined as "the process by which a teacher or more knowledgeable peer provides assistance that enables learners to succeed in problems that would otherwise be too difficult" (Quintana, et al., 2004, p.338) based on Vygotsky's well-known Zone of Proximal Development. For language learning, high challenge and high support learning environments are considered ideal for language learners (Gibbons, 2002; Mariani1997): when the task is challenging and adequate scaffolding is provided, it will be the most beneficial environment for the learners. Instead of simplifying the task, learners should be provided with scaffolding when they are presented with a cognitively demanding task. According to Fortune (2004), the scaffolding techniques that can be used in a CBI course are verbal, procedural, and instructional scaffolding, which include a variety of activities such as paraphrasing, using synonyms and antonyms, grouping, graphic organizers and visuals.

In technology-based learning environments, the technology/tool itself provides the needed scaffolding, rather than a more knowledgeable peer or teacher (Reiser, 2004). The aim of the support is more than accomplishing the task, and with scaffolding, learners learn from the experience, as well.

Quintana et. al (2004) proposed a scaffolding design framework within the area of science inquiry learning, constituting of three main processes, sense-making, process management, and articulation and reflection. Sense making involves basic activities of inquiry, such as creating hypotheses or analysing data. The possible challenges that can be encountered are the difficulty of constructing disciplinary formalism, domain-specific knowledge, and explicit expert strategies. Using language to connect learner's understanding 
with the formalism of the field, and representations where crucial aspects of the information can be explored in different ways are recommended in design. For scaffolding process management, providing learners a structure for difficult tasks, expert guidance about the process, and automatization of the routine tasks are suggested. As for articulation and reflection, scaffolding is particularly needed for those who have difficulty in articulating arguments, who may want to achieve quick outcomes, and those who may have difficulty in planning their learning.

Even though these are formulated within the science inquiry perspective, Quintana's framework provides substantial design guidelines that are crucial for other areas of learning, too, for example, reading online (Zhang \& Quintana, 2012). Some of the guidelines regarding sense making, process management, and articulation and reflection are adopted in the design of the present study. The interactive e-books designed and developed as part of technology integration in this study followed the guidelines particularly about sense making and process management. In order to foster articulation and reflection, a concept book activity was designed where the students' used desktop applications that provided similar scaffolding.

\section{English as a Foreign Language in the Turkish Vocational High School Context}

As stated in the Vocational and Technical Education Strategy and Action Plan (2014), published by the Ministry, Vocational and Technical High Schools are generally preferred by the students who have low academic success in middle school, and their graduates have the lowest success rates in the university entrance exams.

According to the results of a survey conducted in 2012 on the shortcomings of workforce preparation, foreign language skills was the third most frequently cited deficiency, and one of the urgent needs to address was identified as the improvement of foreign language skills in vocational and technical high schools (Gür, et al. 2012). Similarly, the Vocational and Technical Education Action Plan for the years 2014 - 2018 pointed out the need for the improvement of competency in English as a foreign language. The Ministry of National Education aims to increase the quality of language teaching by making English courses more functional for vocational schools. Thus, examining and improving the foreign language curriculum in these schools is essential.

To understand why the students in these schools have little competency in English, several needs analysis studies were carried out over the last two decades (Çelik, 2003; 
Sabuncuoğlu, 2010). An important finding was the students' desire to learn Vocational English in line with their needs and interests (Çelik, 2003; Sabuncuoğlu, 2010). However, Vocational English courses are offered only in certain programs of vocational high schools, such as tourism and cooking (Igrek, 2013). This study is an attempt to address this issue by implementing technology-enhanced CBI with scaffolding, particularly designed and developed for the needs of the students in the child development program of a vocational high school, and assess the effects of such an intervention on content and language learning. The child development department was selected for an exploratory implementation, as there are many terms and concepts in this field translated from English, and with the hope to create a model that can be adopted in other areas.

\section{Method}

This is an exploratory study with a quasi-experimental design, which made use of quantitative and qualitative data, with one experimental and one control group, where pre and post-tests were conducted.

\section{Participants}

The participants of the study were 41 eleventh grade students ( 9 males, 32 females) studying in a public vocational high school. Because five of the students were in a special inclusion program, data from their work were not included in the final analysis. Hence the experimental group consisted of 20 students (4 males, 16 females) enrolled in the child development program, and the control group included 16 students (5 males, 11 females) from the nursing program. Both of the groups followed an A2.2 level textbook, mandated and distributed by the Ministry of Education for $11^{\text {th }}$ grade. However, the students were below the assumed language proficiency level. Since previously formed classes were used in the study, the groups were conveniently selected. One of the authors was also the English instructor of both of the groups.

The school was located in an impoverished neighbourhood, and served students who received low scores on the national high school entrance exam. The overwhelming majority of the students came from families with low socioeconomic status, with few opportunities to support foreign language education, and some did not have a computer at home. It can be assumed that the students' exposure to technology, except smart phones, was quite limited. 


\section{Materials - Integration of Language, Content, and Technology}

The unit entitled "Health and Nutrition" was selected from the English textbook Yes You Can A2.2, and the unit on Child Nutrition was selected from the course Child Self-care from the $12^{\text {th }}$ grade vocational curriculum. The content of the CBI lessons was thus formed by combining two units, one from their current English as a foreign language (EFL) curriculum, and one from the content area course which the students were to take the following year.

The technology and content integrated materials comprised of five interactive ebooks, an augmented reality activity, digital story-telling, and paper-based concept book writing. The activities required individual, pair, or group work. In addition, video watching activities were designed, and playing an online game in the content area was included. In order to combine real world with virtual world experiences, a freely available Augmented Reality application was selected, and student-recorded short presentations were integrated into vocabulary activities. After completing the five e-books on the computer, each student developed part of a concept book in Storybird, intended to teach children about healthy and unhealthy food, based on a hard copy version they designed in groups.

Interactive e-books

The instructional design of the e-books was based on scaffolding design guidelines for inquiry software (Quintana et al., 2004) that are appropriate for language learning, the principles of multimedia learning (Mayer, 2014), and the EFL objectives and content of the vocational area. All of the books were developed for the study in Articulate Storyline, which allows quick incorporation of verbal and visual information, and offers a set of adjustable quiz templates.

The interactive e-books presented in 5 episodes the story of a teenager who was taking care of her niece and nephew. The story was composed by the authors to integrate the grammatical structures and language usage with the content area of one of the units in the child development curriculum.

The design features in the e-books inspired by Quintana et al (2004)'s scaffolding framework were visual conceptual organizers, multiple representations, and informative feedback to ensure the sense making process. Complex tasks were divided into smaller parts, and ordered checklists were embedded in all of the readings to facilitate process management. In addition, easy switch between the glossary and main content was provided to facilitate navigation within the tool. Opportunities for articulation and reflection was 
provided via Storybird, a desktop application that supports writing skills by providing visual and verbal prompts. All responses to quiz questions were provided with informative feedback (see the Figure below for sample screenshots).

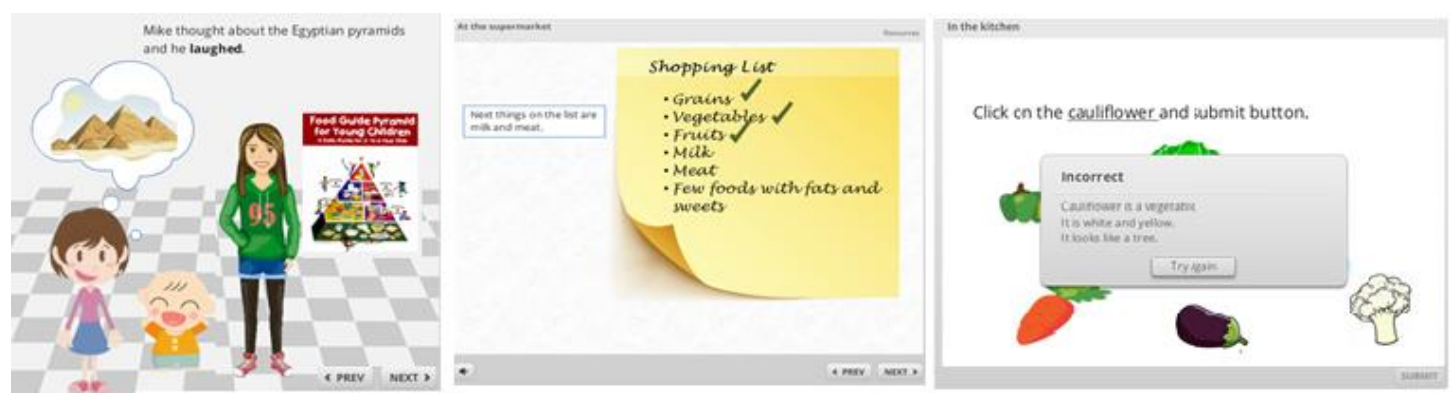

Fig. Sample screenshots from one of the e-books with informative feedback.

\section{Instruments and Procedures}

The English lessons were offered for 80 minutes twice a week in both experimental and control groups as part of their regular course schedule. The entire intervention lasted 5 weeks. There was no computer lab in the school. Due to the limited technology conditions, a total of 5 laptop computers were secured by the teacher/researcher and the students worked in groups of 5 . The station model was employed so that each student had individual access to the e-books and other technology-based activities.

During the intervention, the experimental group followed technology and content integrated activities. No explicit grammar or language instruction was provided. The control group followed the regular textbook with explicit grammar instruction. The grammatical structures and the target vocabulary covered were identical in both of the groups. In addition to the vocabulary items, the experimental group practiced other content related words about child nutrition. The class work evaluated to assess learning outcomes in the experimental group were individual Storybird books, the concept book developed in groups, the individual presentation videos, and the healthy recipe writing task. The same writing task was also carried out in the control group.

The groups were given two pre-tests on content knowledge, one in Turkish and one in English, and two pre-tests on language achievement-a unit exam, and a general language test. In the middle and end of the implementation, the participants in the experimental group were asked to respond to feedback questions. In the first round, the questions were about difficulty/challenges, enjoyable aspects, what the participants have learned so far, and what 
needed to be changed. The feedback collected at the end asked about the students' opinions about the benefits and drawbacks of the implementation, and its effects on their motivation to learn English. The participants also evaluated the effectiveness of the scaffolding features in the e-books on a 5-point Likert-scale, and provided feedback for the overall implementation.

Data Scoring

The unit exam included vocabulary, reading comprehension, grammar and writing questions with a maximum score of 100. The general language test included vocabulary and grammar questions, such as odd one out, true/false, and choose the correct one, with a maximum score of 35. The content test in English was worth 10 points in total, and the one in Turkish was 20 points. The Cronbach's Alpha was found .817.

As for feedback from the participants, the experimental groups' responses on the fivepoint Likert scale were added up, and a total score was calculated for each scaffolding feature. Then the average for each scaffolding feature was calculated for an effectiveness score of each component. They were tallied and grouped depending on when the feedback was collected.

All written tasks were assessed using Brown (2000)'s rubric in terms of content, organization, accuracy, vocabulary, spelling, and punctuation. Each section was worth five points. The total score was 25 . The hard-copy concept books were designed in groups, but each student was required to design one page. Thus an individual assessment was possible. The class work for speaking performance was assessed using a presentation rubric created by Toth (2010), for eye contact, enthusiasm, preparedness and organization, speaking clearly, and knowledge of content. The maximum possible score was 25 points. An independent rater, who was also a teacher of EFL graded each class work in order to ensure interrater reliability.

\section{Data Analysis}

When the data from the pre and post tests were checked for normality of distribution, it was found that not all the scores were normally distributed. After a square root transformation, the data from general language test and the Turkish content test met the normality assumption, while the unit exam and the English content test scores were still not normally distributed. A $2 \times 2$ ANOVA was applied to compare the results from the general language test, since the two groups were tested twice at two different times. This would 
allow to test for interaction, and all of the data would be taken into account when estimating the variance components.

The pre-test means of the Turkish content test showed a significant difference between the experimental and control group, indicating that the two groups were not equal at the beginning. Therefore, gain scores were calculated to eliminate the possible effect of pre-test scores on the post-test. The Kruskal-Wallis $\mathrm{H}$ test was carried out as a nonparametric alternative to ANOVA to compare the mean scores from the unit exam and the English content test given at two different times. Additionally, the scores from a recipe writing task, which was part of in-class work in both the groups, were also normally distributed, and one way ANOVA was conducted to compare the means of the two groups.

To compare each group's pre-test scores to their post test scores, paired samples t-test was used where the data was normally distributed, so that within subject changes could be detected. For the scores that were not normally distributed, the related samples Wilcoxon signed rank test was applied to compare pre and post test scores.

Finally, the responses to the open ended questions on the user feedback questionnaire were descriptively analysed. They were sorted and categorized based on the theme each question addressed: difficulty/challenges, aspects enjoyed, learning, benefits and drawbacks of the implementation, motivational effects, and suggestions for change.

\section{Findings}

The descriptive statistics showed an increase in the mean scores of both the experimental and control groups from the pre to post-test in all four measures of language and content, as can be seen in Table 1 below.

Table 1. Experimental and Control groups' scores from pre and post tests

\begin{tabular}{llllll}
\hline & & $\begin{array}{l}\text { Pretest } \\
\text { Mean }\end{array}$ & SD & Posttest \\
Mean & SD \\
\hline General & Experimental & 14.25 & 3.3 & 19.15 & 2.9 \\
language test & Control & 13.25 & 5.1 & 17.5 & 3.1 \\
\hline Unit Exam & Experimental & 22 & 8.7 & 39 & 16.4 \\
& Control & 20.2 & 11.4 & 27.6 & 16.1 \\
\hline Content test & Experimental & 2.3 & 0.98 & 3.9 & 1.1 \\
English & Control & 2.31 & 1.25 & 2.4 & 1.1 \\
\hline Content test & Experimental & 10.75 & 1.99 & 15.1 & 1.9 \\
Turkish & Control & 7.13 & 2.65 & 8 & 3.2 \\
\cline { 2 - 5 } & & &
\end{tabular}




\section{Language Gains}

The $2 \times 2$ ANOVA conducted on the general language test scores revealed that there was a significant main effect for time, which meant that the experimental and the control groups both showed a significant difference from the pre- to the post-test. The mean score of the experimental group was a bit higher, but the main effect for group was not significant $(F(1,34)=1.182, p=.285)$, nor was the main effect for Time $x$ Group $(F(1,34)=2.421, p=.129)$. Hence there was no significant difference between the two groups regarding the general language test scores.

Since the implementation had targeted vocabulary and grammar, the scores from these sections were also compared separately. An increase in each subtest was observed in the mean scores of both the groups, as can be seen in Table 2. A paired samples t-test conducted on the vocabulary and grammar sections showed that the experimental group's scores showed a significant difference from the pre- to post test in all three sections, i.e. two vocabulary $(p=.009, p=.001)$ and one grammar section $(p=.002)$, while the control group showed significant improvement in two of the subtests.

Table 2. Mean scores for vocabulary and grammar sections from the general language test

\begin{tabular}{llllll}
\hline & & $\begin{array}{l}\text { Pretest } \\
\text { Mean }\end{array}$ & SD & Posttest \\
Mean & SD \\
\hline Vocabulary 1 & Experimental & 6.85 & 5.6 & 8.25 & 1.6 \\
& Control & 5.7 & 2.2 & 8.19 & 1.75 \\
\hline Vocabulary 2 & Experimental & 2.8 & 1.8 & 4.65 & 2.05 \\
& Control & 3 & 2.2 & 3.3 & 1.66 \\
\hline Grammar & Experimental & 4.6 & 1.9 & 6.25 & 1.1 \\
& Control & 4.5 & 2.4 & 6 & 1.67 \\
\hline
\end{tabular}

The Kruskal-Wallis $\mathrm{H}$ test carried out on the pre-test scores showed that the experimental and control groups were found to be almost equal before the implementation $(\mathrm{p}=.425)$. When the post-test scores of the groups were compared, a significant difference was found between the experimental and control group $(p=.030)$. The experimental group outperformed the control group in the post unit exam.

Finally, within group comparisons were conducted to see whether or not each group exhibited a significant gain from the pre to post test in any of the measures. A related samples Wilcoxon signed rank test revealed a significant difference between the pre and post test scores of the experimental group $(p=.010)$. The difference between the pre and post-test scores of the control group was also significant $(p=.017)$, based on a paired-samples t-test. 


\section{Content Knowledge Gains}

Since the scores of the content knowledge test in English were not normally distributed for either of the groups, non-parametric tests were conducted. Kruskal-Wallis $\mathrm{H}$ test demonstrated that the pre-test scores were not significantly different between the experimental and control groups $(p=.855)$. The post-test scores of the same test, on the other hand, were significantly higher for the experimental group $(p=.001)$. As for the differences between each group's pre and post test scores, a related samples Wilcoxon signed rank test showed a significant difference in the experimental group $(p=.000)$, The scores of the control group showed no significant difference from the pre to the post test in English $(p=1.000)$, as expected.

A one-way ANOVA on the gain scores of the Turkish content test revealed a significant difference between the two groups $(p=.000)$; the experimental group $(M=4.35$, $\mathrm{SD}=1.49)$ outperformed the control group $(\mathrm{M}=.95, \mathrm{SD}=2.51)$ in the content knowledge test $F(1,34)=25.598, p=.000)$. As for the difference within the experimental group itself, there was a significant difference between their pre and post-test scores $(p=.000)$ as opposed to the control group $(p=.157)$.

\section{Participant Feedback}

The participants' responses about the challenges they faced during the implementation in the experimental group fell into 3 categories: difficulties regarding extraneous load, i.e. design-related, those related to language, and no difficulty. Twelve participants $(\mathrm{N}=20)$ indicated that they did not experience any difficulty during the implementation, whereas six students said some of the components were challenging for them, mostly, preparing a presentation. The most frequently cited enjoyable aspect was the technology integration: reading on the computer, and using Aurasma. The content related activities, such as creating a food pyramid, were cited by 12 participants as the most enjoyable. Ten students indicated that language achievement activities such as making a presentation and speaking in English were most enjoyable for them.

The responses about what the students learned were grouped into two: languagerelated gains and content-related gains. Fifteen participants claimed that they had learned new information about content, while twelve participants listed language related learning, such as grammar topics and vocabulary items. Finally, in response to what needed to be 
changed, two students indicated that the number of new vocabulary should be decreased, one student suggested that the number of the tests be decreased.

The feedback collected at the end of the study revealed that 17 participants $(\mathrm{N}=20)$ found the implementation enjoyable when their overall assessment was asked. Six students claimed that they had learned a lot and defined the study as instructive. Twelve students indicated that they were highly-motivated to learn English at the end of the study. Two students considered themselves already highly-motivated, and one said their motivation increased somewhat. As for the reason for increase in motivation, four students reported the language gains they had achieved throughout the implementation, and two said that it was due to the theme-based instruction. In responses to the benefits and drawbacks, 18 students $(\mathrm{N}=20)$ mentioned no negative aspects. As for the positive aspects, eight students mentioned learning new vocabulary, and four learning new information in general. Other beneficial aspects listed were group work, learning content area knowledge, and the increase in motivation.

The 5-point Likert-scale results showed that the two most beneficial scaffolding features according to the participants were the picture dictionary with definitions and translations, and the salient food pyramid visual. The other useful features were the to-do list and the shopping lists that showed user progress and what to come next. However, comparing different types of cooking the same food, various representations of the food pyramid, and examining the nutrients in food were not found as effective as the others.

\section{Class Work}

A one-way ANOVA conducted on the mean scores from the "healthy recipe" task showed that the experimental group $(\mathrm{M}=17.95, \mathrm{SD}=3.22)$ significantly outperformed the control group $(M=13.50, S D=3.61)$ in this writing task, which was done in both of the groups $F(1,34)=15.23, p=.000)$.

In the experimental group, the mean score for the print version of the concept book was 21.7. The scores of the book pages developed by each student ranged from 19-24.5 $(\mathrm{SD}=1.46)$. The mean score obtained from the online part of the task was 16.1, while the range was 13-19 $(\mathrm{SD}=1.77)$. As for the presentation task, the mean score was $18.4(\mathrm{SD}=4.25)$. Two students achieved the highest score of 25, while the rest of the scores ranged from 9-24. 
The final class work that the students in the experimental group completed was responding to the interactive items in the e-books. The students responded to the embedded questions correctly $67.9 \%$ on average in the first e-book $(\mathrm{N}=7), 83.9 \%$ in the second e-book $(\mathrm{N}=5)$, and $95.7 \%$ in the third one $(\mathrm{N}=6)$. All the students, except two, consistently improved their scores from the first to the third book, as can be observed in Table 3. The percentages of correct answers obtained from the last e-book varied from $60-100 \%(\mathrm{~N}=6)$. Although the mean score was lower than the second or third e-books, all of the students scored higher in the fourth e-book than they did in the first one.

Table 3. Percentages of correct responses to interactive items in e-books

\begin{tabular}{lllll}
\hline & Book 1 & Book 2 & Book 3 & Book 4 \\
\hline Student1 & 64.7 & 100 & 100 & 70 \\
Student2 & 52.9 & 73.6 & 92.8 & 60 \\
Student3 & 76.4 & 100 & 92.8 & 80 \\
Student4 & 64.7 & 78.9 & 100 & 70 \\
Student5 & 52.9 & 100 & 92.8 & 60 \\
Student6 & 76.4 & 84.2 & 100 & 70 \\
Student7 & 82.3 & 89.4 & 92.8 & 80 \\
Student8 & 58.8 & 68.4 & 100 & 60 \\
Student9 & 76.4 & 89.4 & 100 & 80 \\
Student10 & 58.8 & 73.6 & 92.8 & 90 \\
Student11 & 70.5 & 78.9 & 100 & 70 \\
Student12 & 76.4 & 84.2 & 85.7 & 80 \\
Student13 & 64.7 & 73.6 & 85.7 & 70 \\
Student14 & 70.5 & 100 & 100 & 80 \\
Student15 & 70.5 & 78.9 & 85.7 & 90 \\
Student16 & 76.4 & 84.2 & 100 & 100 \\
Student17 & 70.5 & 84.2 & 100 & 80 \\
Student18 & 58.8 & 68.4 & 92.8 & 70 \\
Student19 & 64.7 & 73.6 & 100 & 70 \\
Student20 & 70.5 & 94.7 & 100 & 70 \\
& & & & \\
\hline Means & $67.94 \%$ & $83.95 \%$ & $95.71 \%$ & $75 \%$ \\
\hline
\end{tabular}

\section{Discussion and Conclusions}

The purpose of this exploratory study was to design, develop, and evaluate technology and content integration for vocational high school English, based on CBI design on the one hand, and scaffolding design guidelines on the other. A comparison of test scores showed that the experimental group outperformed the control group in content tests in both Turkish and English, the English unit exam, and the in-class writing task, although no significant difference was found between the two groups in the general language test. This confirms findings from earlier studies where integrating content into foreign language 
classes showed better content learning (e.g. Coyle, 2006; Seikkula-Leino, 2007; Snow \& Brinton, 1988).

In addition to content learning, the improvement of language test scores in this study is also in line with the literature. The experimental group improved their scores from the pre and post-test in all four measures, while the control group improved only in the general language test and the unit exam. This result can be explained with Cummins (1984)'s quadrant for the analysis of language tasks. In the content and technology integrated design implemented here, cognitively demanding and context-embedded tasks that improve higher thinking skills were chosen, and consequently, better content and language learning occurred. Similarly, as Bereiter and Scardamalia (1993) suggested in their theory of expertise, learners in content integrated language classes experience increased but manageable task complexity, which is an appropriate way to gain expertise.

The advocates of content integration claim that the students in CBI type of classes will not fall behind those who receive mainstream foreign language instruction in language achievement tests, even if the explicit grammar explanation is not the only focus (Georgiou, 2012; Snow \& Brinton, 1988). Similarly, the experimental group in this study was able to compete with the control group in the general language test as implied by the no significant difference, which is compatible with the literature (e.g. Manzano-Vázquez, 2014). More importantly, they were also able to score significantly higher than the control in the unit test and writing task, in contrast to findings from other studies, where no significant difference was found for writing and vocabulary (Agustín-Llach, 2017; Gierlinger \& Wagner, 2016). Snow, Met, and Genesee (1989) argued that integrating content and language helps create a meaningful academic context, which would result in simultaneous language and content mastery, rather than separate or sequential learning of each (Wesche \& Skehan, 2002). In this study, both comprehensible language input was presented in the target language as proposed by Krashen (1982), and accessible content was offered, as Zhao and Dixon (2017) suggested in their extension of Krashen's work. Thus comprehensible and meaningful language input in a technology-enhanced learning environment helped increase language gains.

That the experimental and control groups showed similar performance on the general language test can also be due the unfamiliarity of the question formats in this test, such as odd-one-out and grammatical judgment, which require more than simple language 
knowledge to respond correctly. Since the students were below the assumed language proficiency level A2.2 based on their speaking and writing skills, they might have had to deal with higher extraneous cognitive load when responding to types of questions they were not familiar with.

The gradual increase in the e-book question scores, and the participant feedback regarding the scaffolding features in the experimental group could be interpreted as an evidence for the success of incorporating Quintana et al (2004)'s scaffolding design guidelines for educational software. The students' increased performance on the interactive elements in the e-books also support the claim for effectiveness of scaffolds, such as ordered and unordered checklists, decomposing the task into smaller pieces to help process management, and visual conceptual organizers to facilitate the sense making process. Since these scaffolds provided a sort of expert guidance, the students stepped further to a point where they would have difficulty reaching alone.

The informative feedback provided in the e-books could also have factored into the significant difference the experimental group secured in content knowledge. Lightbown (2014) stated that the feedback provided in content-integrated language classes was highly beneficial to the learners. Similarly, Sagarra and Zapata (2008), and Mackey, Gass and McDonough (2000) affirmed that students benefit from computer generated informative feedback more than the traditional immediate feedback just stating try again, and right or wrong.

The learning outcomes measured via tests were compatible with the feedback from the students in the experimental group, stating that they enjoyed the content related language activities: "I learned about the food pyramid, nutrition for children, and also some new words in English." That the students eventually indicated that they liked presenting in English, in complete contrast to what they had said in the first feedback, showed that they were able to deal with the challenge of presenting in a foreign language when provided with sufficient scaffolding. This was evident in some of their feedback: "I realized that I was able to speak in English during the presentations, although I did not feel that I could at the beginning." This is consistent with the findings that students can increase their levels of fluency in a foreign language when instruction is designed to integrate content and include appropriate support (Loewen \& Sato, 2019). In that sense, this study achieved one of the 
aims of the CBI approach, which is to use authentic and interesting media to create an environment where students enjoy learning the target language (Short, 1991).

The comments in the feedback received half way through the implementation related to the challenge of presentation were absent in the feedback collected at the end. Moreover, even if presenting in the classroom was found challenging, the students were able to perform at a considerable level, which indicates when students are challenged within their zone of proximal development (Vygotsky, 1978), using appropriate technology, they can extend their language skills. This was evident in one student's feedback: "I realized that I was able to speak in English in the presentations, although I did not feel that I could at the beginning."

The students' responses to what they learned were mainly about content and language gains, which is also evident in the significant difference between their pre and post test scores in both content and unit tests. When asked what to change during and the end of the implementation, all students responded that the design was fine as is. This can be attributed to the motivating aspect of technology integration, as shown by various researchers (e.g. Jamieson \& Chapelle, 2008; Thomas, 2009; Sauro \& Chapelle, 2017; Ismajli, \& Krasniqi, 2018). That the students were positive about technology integration is also compatible with the findings that the use of technology is perceived as a motivating strategy in foreign language classes (Kennedy, 2006). Most of the students rated themselves as highlymotivated at the end of the intervention, and indicated that language and content gains were the reason for their motivation.

It is possible to attribute the positive feedback to a novelty effect, since what the students experienced during the implementation was brand new for them. However, the reason for integrating technology and content was to create an engaging language learning environment, where the content is compatible with the students' area of study, and thus personally relevant to them. Therefore, this effect seems a natural and desirable outcome. Another possible reason for the students' positive feelings about the implementation might be that learning content related vocabulary is a good way to prepare for their future career, as stated by Coyle, Hood, and Marsh (2010).

\section{Implications for Research and Practice}

The findings can be useful for future researchers, instructional designers, English language teachers working in vocational high schools, and policy makers, in favour of 
content and technology enhanced language lessons. Creating cross-curricular links between the content area and language requires a huge amount of work, but the results are promising. Therefore, vocational English courses following a content integrated approach might be offered by the Ministry of Education more widely. English lessons in vocational schools could be designed based on the particular program students are enrolled in, which would offer a meaningful purpose to learn a new language.

Vocational English courses were recently included in the curriculum in a number of vocational departments-this should be applied in all specialization areas. Following a content and technology integrated approach in these Vocational English courses rather than the regular English textbook would be more beneficial for the students. Unfortunately, the Ministry reduced the number of English lessons per week in vocational high schools in 2017. It should be noted that the more the learners are exposed to the target language, the higher are their chances to learn it. Therefore, instead of decreasing the number of lessons, policy makers should take action to help create a motivating language learning environment where the students' needs and areas of interest are taken into consideration.

This study was generally focused on vocabulary and reading skills. When more time is devoted to this kind of research, the four language skills can be balanced more equally, and thus robust findings could be obtained for all of the skills involved. Similarly, various types of feedback might be integrated into the e-books, and the effect of each type of feedback on content and language learning could be evaluated. Especially, embedding content-focused or language-focused feedback into the e-books would be an area of research that needs to be explored.

\section{Limitations}

A major limitation in this study was caused by the physical conditions of the research site, such as the lack of a computer lab or computers, and a reliable network connection in the school, which had to be resolved by the teacher/researcher's own resources. Another limitation was that the two control and experimental groups were from two different vocational areas, even if closely related.

The duration of the study was another limitation. A gradual decrease of scaffolds in the e-books could not be implemented due to time constraints. Instead, there was a steep decrease in the number of scaffolds from the third to the last e-book, which resulted in a 
visible decrease in the students' scores. Designing and testing interactive EFL e-books supported with different amounts and types of scaffolds would provide a better insight about the type and amount of scaffold that is most beneficial for this learner profile. As Reiser (2004) indicated, finding a balance in the amount of scaffolding can be a delicate issue.

As the number of scales to measure content mastery is scarce, and the participants had limited English, the content and language tests were designed specifically for this study, in cooperation with a content teacher at the school and with two area experts in teaching English as a foreign language. Since it was an exploratory study with instructional design as the main focus, these customized tests were considered sufficient.

\section{Acknowledgement}

This study was approved by Boğaziçi University INAREK / SBB Ethics sub-committee with the permission of SBB-EAK 2017/29. The data used in this study was confirmed by the researchers that it belongs to the years before 2020.

Authorship Contribution Statement

Ebru ATADIL-KUZUCU: Design and development, methodology, data curation, formal analysis, writing-original draft

Günizi KARTAL: Conceptualization, methodology, supervision writing-reviewEediting

\section{References}

Agustín-Llach, M. P. (2017). The effects of the CLIL approach in young foreign language learners' lexical profiles. International Journal of Bilingual Education and Bilingualism, 20(5), 557-573.

Alptekin, C., Erçetin, G., \& Bayyurt, Y. (2007). The effectiveness of a theme-based syllabus for young L2 learners. Journal of Multilingual and Multicultural Development, 28(1), 1-17.

Bereiter, C., \& Scardamalia, M. (1993). Surpassing ourselves: An inquiry into the nature and implications of expertise. Chicago: Open Court.

Bransford, J. D., Brown, A. L., \& Cocking, R. R. (2000) How people learn. Brain, mind, experience, and school. National Academy Press, Washington, D.C.

Bush, M. D., \& Terry, R. M. (Eds.). (1997). Technology-enhanced language learning. Lincolnwood, IL: National Textbook Company.

Carrel, P. L., \& Carson, J. G. (1997). Extensive and intensive reading in an EAP setting. English for Specific Purpose, 16(1), 47-60. 
Chapelle, C., \& Jamieson, J. (2008). Tips for teaching with CALL: Practical approaches to computer-assisted language learning. USA: Pearson Education.

Coral, J., Lleixà, T., \& Ventura, C. (2018). Foreign language competence and content and language integrated learning in multilingual schools in Catalonia. International Journal of Bilingual Education and Bilingualism, 21(2), 139-150.

Coyle, D. (2006). Content and language integrated learning: motivating learners and teachers. Scottish Languages Review, 13, 1-18.

Coyle, D., Hood, P. \& Marsh, D. (2010). Content and language integrated learning. Cambridge: Cambridge University Press.

Crandall, J. A. (1993). Content-centered language learning in the United States. Annual Review of Applied Linguistics, 13, 111-126.

Cummins, J. (1984). Bilingualism and special education: Issues in assessment and pedagogy. Clevedon, England: Multilingual matters.

Çelik, S. (2003). Niğde Üniversitesi meslek yüksekokullarındaki büro yönetimi ve sekreterlik bölümü öğrencilerinin akademik ve mesleki İngilizce gereksinimlerine yönelik bir araştırma. [A study on student needs regarding academic and vocational English at the Niğde University Vocational School] (Unpublished master's thesis). Bilkent University, Ankara.

Erçetin, G. (2011). Pedagogical issues in developing mobile assisted language learning materials. Boğaziçi University Journal of Education, 28(1), 22-30.

Georgiou, S. I. (2012). Reviewing the puzzle of CLIL. ELT Journal, 66(4), 495-504.

Gibbons, P. (2002). Scaffolding language, scaffolding learning: Teaching second language learners in the mainstream classroom. Portsmouth, NH: Heinemann.

Gierlinger, E., \& Wagner, T. (2016). The more the merrier-Revisiting CLIL-based vocabulary growth in secondary education. Latin American Journal of Content $\mathcal{E}$ Language Integrated Learning, 9(1), 37-63.

Graham, K. M., Choi, Y., Davoodi, A., Razmeh, S. \& Dixon, L. Q. (2018). Language and Content Outcomes of CLIL and EMI: A systematic review. LACLIL, 11(1), 19-37. DOI: 10.5294/lacli1.2018.11.1.2

Gür, B. S., Özoğlu, M., Akgeyik, T., Çetimkaya, E., Karagöl, E. T., Öztürk, M., ... \& Çelik, Z. (2012). Türkiye'nin insan kaynağının belirlenmesi. [Determining Turkey's human resources] SETA.

Haley, M. H., \& Austin, T. Y. (2013). Content-based second language teaching and learning: An interactive approach. Boston: Pearson Higher Ed.

İgrek, E. (2013). İçerik tabanl yabancı dil öğretim yaklaşımının mesleki yabancı dil (Ingilizce) derslerinde öğrencilerin akademik başarılarına etkisi. [The effects of CBI on students' academic performance in vocational foreign language (English) courses] (Unpublished master's thesis). Gazi University, Ankara.

Ismajli, H., \& Krasniqi, D. (2018). Challenges for achieving learning outcomes of languages and communication curriculum area in primary education in kosovo. International eJournal of Educational Studies (IEJES), 2(4), 81-91. 
Kasper, L. F. (2000). The Internet and content-based college ESL Instruction. In Kasper, L. F. (Ed.) Content-based college ESL instruction, (pp. 183-201). Mahwah, N. J. : Lawrence Erlbaum Associates.

Kennedy, T. J., \& Henderson, S. (2003). The GLOBE program: Bringing together students, teachers and scientists to increase scientific understanding of the Earth through research. Children, Youth and Environments, 13(2), 217-227.

Krashen, S. (1982). Principles and practice in second language acquisition. Oxford: Pergamon Press.

Lightbown, P. M. (2014). Focus on content-based language teaching--Oxford key concepts for the language classroom. Oxford: Oxford University Press.

Loewen, S. \& Sato; M. (2019) Instructed second language acquisition and English language teaching. In Gao, X. (Ed.) Second Handbook of English Language Teaching. Springer International Handbooks of Education. Springer, Cham.

Mackey, A., Gass, S., \& McDonough, K. (2000). How do learners perceive interactional feedback? Studies in second language acquisition, 22(4), 471-497.

Manzano-Vázquez, B. (2014) Lexical transfer in the written production of a CLIL group and a non-CLIL group. International Journal of English Studies, 14(2), 57-76.

Marsh, D., Mehisto, P., Wolff, D., \& Frigols Martin, M. J. (2010). European framework for CLIL teacher education: A framework for the professional development of CLIL teachers. Graz: European Centre for Modern Languages.

Mariani, L. (1997). Teacher support and teacher challenge in promoting learner autonomy. Perspectives: A Journal of TESOL Italy, 23 (2), 5-19.

Maxwell-Reid, C. (2010). Content and Language Integrated Learning (CLIL): The influence of studying through English or Spanish students' first-language written discourse. Text E Talk, 30(6), 679-699.

Prensky, M. (2001). Digital natives, digital immigrants part 1. On the horizon, 9(5), 1-6.

Quintana, C., Reiser, B. J., Davis, E. A., Krajcik, J., Fretz, E., Duncan, R. G., ... \& Soloway, E. (2004). A scaffolding design framework for software to support science inquiry. The Journal of the Learning Sciences, 13(3), 337-386.

Reiser, B. J. (2004). Scaffolding complex learning: The mechanisms of structuring and problematizing student work. The Journal of the Learning Sciences, 13(3), 273-304.

Sabuncuoğlu, A. (2010). Meslek liselerinde özel amaçl İngilizce öğretimine yönelik gereksinim çözümlemesi uygulaması. [Implementation of needs analysis for teaching English for a special purpose at vocational high schools] (Unpublished master's thesis). Ankara University, Ankara.

Sagarra, N., \& Zapata, G. C. (2008). Blending classroom instruction with online homework: A study of student perceptions of computer-assisted L2 learning. ReCALL, 20(2), 208224.

Sauro, S., \& Chapelle, C. A. (2017). Toward langua-technocultural competence. In Chapelle, C. A. \& S. Sauro (Ed.s). The Handbook of Technology and Second Language Teaching and Learning, (pp. 459-471). Hoboken, N.J.:Wiley Blackwell. 
Seikkula-Leino, J. (2007). CLIL learning: achievement levels and affective factors. Language and Education, 21(4), 28-41.

Short, D.J. (1991). How to integrate language and content instruction: A raining manual. Washington, DC: Center for Applied Linguistics.

Snow, M. A., \& Brinton, D. (Eds.). (1997). The content-based classroom: Perspectives on integrating language and content. White Plains, NY: Longman.

Snow, M. A., Met, M., \& Genesee, F. (1989). A conceptual framework for the integration of language and content in second/foreign language instruction. TESOL Quarterly, 23(2), 201-217.

Stryker, S. B., \& Leaver, B. L. (Eds.). (1997). Content-based instruction in foreign language education: Models and methods. Washington, DC: Georgetown University Press.

Thomas, M. (Ed.). (2009). Handbook of research on Web 2.0 and second language learning. USA: IGI Global.

Toth, S. (2010). Oral presentation rubric. Retrieved June 20, 2017, from https://studylib.net/doc/7752853/oral-presentation-rubric

Wesche, M., \& Skehan, P. (2002) Communicative teaching, content-based instruction, and task-based learning. In R. Kaplan (Ed.), Handbook of applied linguistics (pp. 207-228). Oxford: Oxford University Press.

Vygotsky, L. S. (1978). Mind in society: The development of higher psychological processes. USA: Harvard University Press.

Yalçın, Ş. (2012). Content-based instruction at the tertiary level in Turkey. In Y. Bayyurt \& Y. Bektaş-Çetinkaya (Eds.), Research perspectives on teaching and learning English in Turkey: Policies and practices (pp. 217-234). Frankfurt: Peter Lang.

Yalçın, Ş. (2013). İçerik temelli yabancı dil öğretim modeli [Content-based instruction model in foreign language teaching]. Boğaziçi University Journal of Education, 30(2), 107-122.

Yang, W. (2015). Content and Language Integrated Learning next in Asia: Evidence of learners' achievement in CLIL education from a Taiwan tertiary degree programme. International Journal of Bilingual Education and Bilingualism, 18(4), 361-382.

Zhang, M., \& Quintana, C. (2012). Scaffolding strategies for supporting middle school students' online inquiry processes. Computers $\mathcal{E}$ Education, 58(1), 181-196.

Zhao, J., \& Dixon, L. Q. (2017). English-medium instruction in Chinese universities: Perspectives, discourse and evaluation. New York, NY: Routledge.

JCER's Publication Ethics and Publication Malpractice Statement are based, in large part, on the guidelines and standards developed by the Committee on Publication Ethics (COPE). This article is available under Creative Commons CC-BY 4.0 license (https://creativecommons.org/licenses/by/4.0/) 